\title{
FORMATION OF INFORMATION IMMUNITY AS \\ GUARANTY OF INCREASING INFORMATION CULTURE OF PEOPLE
}

\author{
Sanaqulov Abror Nazarovich \\ Senior Lecturer at Tashkent University \\ Information Technologies named after \\ Muhammad al-Khwarizmi
}

Аннотация. В статье рассматриваются вопросы формирования информационно культуры в рамках дальнейшего развития демократических реформ в Узбекистане. Определены угрозы информационной безопасности общества.

Annotation: The article deals with the formation of information culture in terms of the further development of democratic reforms in Uzbekistan. Some threats to the information security of the society are identified.

Ключевые слова: информация, информационная культура, глобализация, Интернет, защита информации.

Keywords: information, informational culture, globalization, Internet, information security

At the present time, the aggressive nature of disseminated information, which has a tremendous impact on people's worldviews, especially on the younger generation is manifested throughout the world more than ever before. Information has become widespread as a factor in promoting and preserving the spiritual values of a certain nation.

The development and improvement of technical and technological methods and means of disseminating, obtaining and storing the information has rebuilt these means (electronic databases and data banks, registries, registers, cadastres and other information resources) into independent cultural values, allowing them to be used. 
The information culture of the population grows with the growth of the information volume, and stable expressions such as "information culture", "information space" etc. appear more frequently in the lexicon of modern people. In our changing world information culture as such and the culture itself becomes an object and a subject of information security at the same time. This is due to the fact that both culture and information have a direct impact on a person's world view, affecting his thinking and perception. «Information culture requires new knowledge and skills from modern man, a special style of thinking, providing the necessary adaptation to social changes and guaranteeing a worthy place in the information environment» [1].

In the global space, the information culture is formed rather chaotically, overcoming various obstacles, and finds its way to the consumer, to man. But one should take into account the fact that the level of information culture of people is diverse. Moreover, as is well known, that not all the information received fosters a spiritual foundations in a person, contributes to his moral improvement.

From this point of view, the problem of formation informational and cultural immunity of a person, who is a consumer of information, is becoming ever so urgent.

Sociological studies show that the majority of disseminated information in the world varied greatly lacking objectivity, often expressing the interests of respective forces.

Based on this, in the Republic of Uzbekistan, in accordance with the principle of "trust, but verify," the task is to form an information culture, to develop the persistence of people's world view, especially among young people.

In the Republic of Uzbekistan this process implants to form an information culture, to develop the persistence of people's world view, especially among young people in accordance with the principle of "trust, but verify".

As the first President of the Republic of Uzbekistan Islam Karimov noted, information wars are currently going on in the world and "ideological testing sites 
have become more dangerous now than nuclear testing ones", which directly affects information security.

The changes in the Republic of Uzbekistan in recent years, the transition to a more open society, create a favorable environment for a wide, free dissemination of information, at the same time increasing public interest in the information itself and directly in the information space.

The need for reliable, objective information and its influence on a person's views requires the adoption of effective measures to prevent the dissemination of hostile ideas and information.

The latest innovative technologies open up unlimited opportunities in all spheres of human activity, but at the same time they create new problems related to the information security of individuals, society and the state.

In the Republic of Uzbekistan such a course of events was foreseen by the first President of the Republic of Uzbekistan Islam Karimov at the time. Thanks to his efforts, a number of proactive measures were taken in the legislative and information environment. Thus, at present, there are more than ten Laws in the Republic dedicated to the freedom of speech and information, its dissemination and security.

The free information environment and globalization, along with the positive moments, led to the appearance of negative factors in the spiritual life of our people.

Now the information is distributed around the world openly, but in many respects it is distinguished by low reliability, outright disinformation, designed to serve the interests of certain forces and states. Therefore, the CIS countries, as well as the Republic of Uzbekistan, have taken appropriate measures to protect not only the information space, but also the information itself and its recipients from information threats and aggression. Thus, Uzbekistan adopted the Laws "On Informatization" and "On Principles and Guarantees of Freedom of Information".

For example, Article 20 of the Law "On Informatization" is devoted to ensuring the protection of information resources and information systems. 
In particular, it states that information resources and information systems are subjects to protection, the improper handling of which may harm their owners, possessors or other legal entities and individuals. State bodies, legal entities and individuals are obliged to ensure the protection of information resources and information systems maintaining confidentiality of information concerning the state. [2].

Article 1 of the Law "On Principles and Guarantees of Freedom" of information states that the main objectives of this Law are:

- information protection as in measures to prevent threats to information security and eliminate their consequences;

- information security as in the state of protection of the interests of the individual, society and the state in the information sphere. [3].

In addition, the Republican Commission coordinates the implementation of the Comprehensive Development Program of the National Information and Communication System for 2013-2020 in the Republic.

Guidelines, programs on information security, which include all measures to ensure information security in the territory of the Republic of Uzbekistan have been developed as the part of the work of this commission. It is obvious that the personal development of every person and the society as a whole is accompanied to a large extent with the development of the information culture of citizens.

Without information culture today it is impossible to build a civil society, which is a factor in the development of democratic principles, a rule of law, stability and prosperity of our country, in which tolerant coexistence of representatives of different cultures, religions and nationalities is ensured. In turn, the further development of Uzbekistan is inextricably linked with the development and improvement of information culture.

Currently, in the scientific world, information is justifiably considered to be a strategic national resource and the basis for the formation of an information culture and world outlook of citizens. The political influence of the Republic of Uzbekistan at the same time gains authority and credibility affecting regional 
events not only in terms of financial and economic factors, but also increasingly, factors of information progress and democratic transformations, such as dialogue with the people, education centers for local services and others. reforms undertaken by the new leadership of the country. Thus, the spread and rooting of spiritual values, culture, language of every nation living in the country is accompanied by confrontation with the spiritual and cultural expansion of certain countries, the spread of mass culture, extremist ideas have become for us a test of strength.

There is a clear shift of the center of gravity from open power methods and means to hidden and more "subtle" information methods and means, served as a result of globalization processes in the rivalry and confrontation of countries in the implementation of their political plans.

It is in this regard that the issues of ensuring information security and ideological and educational work, which should be preventive in stabilizing the sociopolitical, socio-moral situation in the country, are becoming an urgent.

Socio-political activity of citizens of the Republic of Uzbekistan is becoming the foundation of stability and information security. It is known that from the first year of independence the Republic of Uzbekistan receives a kind of social status and name each year, goal of which is one or another layer of people, who need social protection. For example, 2017 was named "the Year of Dialogue with the People and Human Interests". At the initiative of the President of the Republic of Uzbekistan Shavkat Mirziyoyev, folk receptions were created in all regions, which directly study the socio-economic problems of the population, organize outdoor receptions and conduct face-to-face dialogue and take concrete measures to solve the identified problems. Moreover, people can directly contact the virtual reception of the President of the Republic of Uzbekistan. To date, this reception has received more than 2.8 million hits, most of which were positively resolved. [4].

In the recent past, various rumors and speculations of a socio-economic nature were roaming around our lives, our close and distant neighbors, but at present people have no time to deal with these rumors, petty gossips. Now, many critical materials from domestic journalists, human rights activists, bloggers appear 
on the Internet, which, of course, indicates that Uzbekistan firmly stands on the positions of openness and ensuring the development of democratic reforms in the country.

Moreover, every official, every civil servant, knows that he is accountable to the people, his activity is controlled. Now, the principle "Not the people should serve the state, but the state should serve the people!" is being introduced into life in Uzbekistan. Heads of all ranks, including deputies of all levels, periodically report on their activities and inform the people about current affairs and perspective plans.

Any citizen of the Republic of Uzbekistan can submit his complaint, statement or proposal to the virtual reception of the President at any time. Appeals are heard and taken appropriate action in the established timeframe.

Such relations between citizens and the state accelerate the dynamics of information exchange between people and certainly contribute to improving the information culture of citizens. Raising public awareness in such ways has greatly improved the information culture of the people. Now citizens do not believe the rumors and speculation spread via the Internet, because the Internet itself has also begun to fully reflect the changes and transformations that are taking place in the Republic of Uzbekistan.

On September 16, 2013, the Government of the Republic of Uzbekistan adopted a resolution on measures to organize the activities of the e-Government development center and the information security center of the Ministry of Information Technologies and Communications of the Republic of Uzbekistan.

As a result, intensive work is being done everywhere in this direction, which makes it possible to increase the information culture of people and their information security.

In an era of rapid development of information and communication technologies, the Internet and other modern means of communication are becoming an integral part of everyday life, even in the most remote areas of our country. The effect of the introduction of modern ICT is increasing every year, 
electronic document flow is developing and software of all levels of production and business is being improved.

In all areas, information and communication technologies are becoming an important means of exchanging data and providing free, operational services, which leads to a further improvement of the information security culture and, in general, the culture of citizens of the Republic of Uzbekistan.

\section{References}

1.Полякова Г.В. Информационная культура в современном обществе: философские аспекты. Автореф. дис.....канд.филос.наук. - М.2015.С.3.

2.Закон Республики Узбекистан от 11 декабря 2003 г. № 560-II «Об информатизации» // (Ведомости Олий Мажлиса Республики Узбекистан, 2004 г., № 1-2, ст.10; Собрание законодательства Республики Узбекистан, 2014 г., № 36, ст. 452)

3.Закон Республики Узбекистан от 12 декабря 2002 г.,№ 439-II «О принципах и гарантиях свободы» // (Ведомости Олий Мажлиса Республики Узбекистан, 2003 г., № 1, ст. 2; 2015 г., № 52, ст. 645; Национальная база данных законодательства, 19.04.2018 г., № 03/18/476/1087)

4. pm.gov.uz 